\title{
Seismic Fragility Analysis of Base Isolated Structure Subjected to Near-fault Ground Motions
}

\author{
Chengqing Liu ${ }^{1,2^{\star}}$, Dengjia Fang ${ }^{1}$, Zhengxi Yan ${ }^{1}$ \\ ${ }^{1}$ School of Civil Engineering, Southwest Jiaotong University, No. 111, North 1st Section of Second Ring Road, Jinniu District, Chengdu, \\ Sichuan, China \\ ${ }^{2}$ Key Laboratory of High-speed Railway Engineering of Ministry of Education, Southwest Jiaotong University, No. 111, North 1st Section \\ of Second Ring Road, Jinniu District, Chengdu, Sichuan, China \\ *Corresponding author, e-mail: Icqjd@swjtu.edu.cn
}

Received: 13 November 2019, Accepted: 26 February 2021, Published online: 05 March 2021

\begin{abstract}
In order to better evaluate the performance of the base isolated structure under the near-fault earthquakes, this paper takes into consideration an existing engineering case study in China as the prototype, and uses OpenSEES platform to establish the nonlinear finite element model of the base isolated structure. The nonlinear response of the isolated structure under the near-fault earthquake is analyzed. The incremental dynamic analysis (IDA) method is used to calculate the damage probability of the structure under the nearfault earthquake, and the fragility curve of the base isolated structure is established. The fragility equation is obtained by nonlinear regression, and the error of fragility equation is analyzed. The results show that the maximum value of the inter-story drift of the upper structure under the action of near-fault earthquake is significantly greater than that under the action of far-fault earthquake. With the increase of seismic intensity, the damage probability of base isolated structure increases nonlinearly, and the maximum response value of horizontal displacement of bearing and inter-story drift of superstructure increases generally. In addition, the exceeding probability of the fragility curve based on PSDA is greater than that based on EDP criterion. When the sample points of the two methods are the same, the exceeding probability points calculated based on PSDA can be regarded as accurate values. The fragility curve based on PSDA may overestimate the exceeding probability to some extent, and the overestimation may be enlarged with the increase of failure stage.
\end{abstract}

\section{Keywords}

near-fault earthquake, base isolated structure, incremental dynamic analysis, damage probability, seismic fragility

\section{Introduction}

In order to reduce the damage of engineering structure in earthquake and reduce the loss caused by earthquake, the energy dissipation configurations, vibration control and base isolation are widely used in practical projects. Since 1970s, the base isolation system has been widely used in building and bridge engineering $[1,2]$. Scholars have made many meaningful explorations and investigations on the isolation system from different perspectives. By setting isolation bearings on the top of the foundation, the fundamental frequency of the building structure can be effectively reduced, which makes the structural frequency exceeding the frequency range of the earthquake excitation, so as to reduce the input energy of the upper structure and achieve the effect of isolation [3-9]. Isolation bearing can be classified into friction based bearing and rubber bearing. According to the different damping of rubber materials, rubber bearings can also be divided into low damping, natural damping and high damping rubber bearings. In order to improve the performance of rubber bearings, additional members are often added to the bearings. According to the various additional members of bearing, it can be divided into lead rubber bearing, fiber rubber bearing, memory alloy rubber bearing, etc. [10].

As the isolation effect of isolation structure is largely dependent on the performance of bearings, scholars have conducted a lot of research on rubber bearings through experiments and numerical methods. The Institute of Industrial Science (University of Tokyo) has carried out a large number of static load tests on ordinary rubber bearings, and studied the horizontal lateral stiffness, vertical 
stiffness, bearing capacity and other mechanical properties of rubber bearings [11]. Abe et al. [12] studied the hysteretic performance and the coupling effect of horizontal restoring force of laminated rubber bearing under multiaxial load by experiments. Jiang et al. [13] carried out the mechanical properties test of the multi-lead rubber bearing and compared with the numerical simulation. Cardone and Gesualdi [14] took temperature as a variable, carried out mechanical tests on rubber bearings, and studied the temperature sensitivity of the hysteresis performance of rubber bearings. Dezfuli and Alam [15] conducted the sensitivity analysis of the fiber rubber bearing with the finite element method, and proposed a multi-index optimization scheme for the bearing design. Makoto et al. [16] first assumed that the upper structure is linear elastic, then established a typical frame structure finite element model with laminated rubber bearings by using hexahedral solid element, and explored the response of the bearings and frames by dynamic time history analysis method. Ahmadipoor and Alam [10] established the finite element model of lead rubber bearing, and analyzed the sensitivity of the mechanical properties (transverse stiffness, vertical stiffness and equivalent viscous damping ratio) of the bearing to the parameters by changing the radius of lead core, the number of rubber layers and other parameters.

At near-fault conditions, the forward directivity of earthquake ground motion often has a huge adverse effect on the engineering structure. The near-fault earthquake ground motion usually demonstrate long period and high amplitude velocity pulse, while the isolation structure has relatively large period, so the detriment of near-fault earthquake ground motion on the isolation structure is more significant [17-19], especially the large displacement of the isolation structure under the action of near-fault earthquake ground motion [20]. Therefore, the influence of near-fault earthquake ground motion should be considered in the practical application of isolated structure. Fang et al. [21] analyzed the correlation between the characteristic parameters of impulsive and non-impulsive ground motions and the displacement response of the structure, and found that impulsive ground motions can amplify the displacement response of the inter-story drift and the displacement response of the isolation layer of the structure, and the amplification effect of the inter-story drift of the lower floor is more obvious. Nagarajaiah and Xiaohong [22] discussed the dynamic response of a USC base isolated structure under the Northridge earthquake. Yang and Agrawal [23] studied the performance of semi-active hybrid control system under the condition of near-fault earthquake. Jangid [24, 25] analyzed the dynamic response of the isolation system of friction pendulum bearing and lead rubber bearing under the condition of near-fault earthquake, and provided the optimization scheme of the isolation system based on the top acceleration and lateral displacement of the support. Providakis [26] has studied the performance of LRB and FPS bearing isolation structures with additional damping under near-fault seismic action. Tajambolian et al. [27] explored the seismic fragility curve of asymmetric TCFP isolated structure under the condition of near-fault earthquake. Mazza et al. [28, 29] conducted a series of studies on the base isolated structure from different perspectives under the condition of nearfault earthquake, including the structural irregularity and the influence of infilled wall.

It can be seen from the previous research that the study on the whole isolation system focuses on the influence of one or more factors on the whole system. The research of isolation bearing mainly focuses on its mechanical properties through experiments or numerical methods, while the research on seismic fragility model of isolation system is relatively less. The seismic fragility curve expresses the relationship between the earthquake intensity and the failure probability of the structure, which is often used to evaluate the performance of the structure in the earthquake [30]. Since the Northridge earthquake in 1994 and Kobe earthquake in 1995, the empirical seismic fragility model has been established by using the seismic survey data [31], which has been widely used in the seismic risk analysis of engineering structures [32]. Therefore, based on the previous research results, this paper selects the most widely used lead rubber bearing as the isolation device, taking the office building of a multi-story reinforced concrete frame isolation structure as the prototype, and studying the seismic fragility of the base isolated structure under the action of near-fault earthquake.

\section{Theory of earthquake action solution of isolated structure}

The establishment and solution of the dynamic equation have an important relationship with the calculation of the dynamic response of the structure under the action of earthquake. Therefore, the establishment and solution of the dynamic equation in this paper are described first. When the earthquake occurs, the basement movement causes the structural response. The total displacement (or absolute displacement) of the structure includes the displacement of the ground and mass relative to the base. 
Taking the single degree of freedom system as an example, its absolute displacement can be determined by the Eq. (1):

$U^{t}=U+U_{g}$,

where, $U_{t}$ is the total displacement (or absolute displacement) of the system. $U$ is the relative displacement, and $U_{g}$ is the base displacement of the system.

In Eq. (1), the ground displacement only causes the rigid body displacement of the structure, but not the elastic force and damping force of the structure. The damping force and elastic force of the system all come from the structural deformation, that is, the dynamic equation of the single degree of freedom system affected by the ground motion can be written as Eq. (2):

$m\left(\ddot{U}+\ddot{U}_{g}\right)+c \dot{U}+k U=0$,

where, $m, c$ and $k$ are the mass, damping and stiffness of the system. $\ddot{U}, \dot{U}$ and $U$ are the relative acceleration, relative velocity and relative displacement. $\ddot{U}_{g}$ is the acceleration of the system base. Eq. (2) can be further rewritten as Eq. (3):

$m \ddot{U}+c \dot{U}+k U=-m \ddot{U}_{g}=P_{\text {eff }}$,

where $P_{\text {eff }}$ is the effective seismic force.

In the establishment of the dynamic equation, the acceleration record of the ground motion is selected as the excitation, which is converted into the equivalent inertial force applied to the structure according to Eq. (3), that is, the effective seismic force, and the non-uniform excitation is not considered. The model of base isolated structure in this paper belongs to multi degree of freedom system, and its dynamic equation can be written as Eq. (4):

$$
[\boldsymbol{M}][\ddot{\boldsymbol{U}}]+[\boldsymbol{C}][\dot{\boldsymbol{U}}]+[\boldsymbol{K}][\boldsymbol{U}]=\left[\boldsymbol{P}_{\text {eff }}\right],
$$

where, $[\boldsymbol{M}],[\boldsymbol{C}]$ and $[\boldsymbol{K}]$ are the mass matrix, damping matrix and stiffness matrix of the structure system. $[\ddot{\boldsymbol{U}}],[\dot{\boldsymbol{U}}]$ and $[\boldsymbol{U}]$ are the acceleration vector, velocity vector and displacement vector. $\left[\boldsymbol{P}_{\text {eff }}\right]$ is the effective seismic force vector.

Considering the nonlinear factors of Eq. (4), this paper uses the direct integration numerical method to solve the partial differential equation. The reaction of the system is separated in time. It is not strictly required that the system meet the dynamic Eq. (4) at all times, but only at a specific point in time. In Fig. 1, the dynamic equations at $i$ and $i+1$ are as follows Eq. (5):

$$
\left\{\begin{array}{l}
{[\boldsymbol{M}][\ddot{\boldsymbol{U}}]_{i}+[\boldsymbol{C}][\dot{\boldsymbol{U}}]_{i}+[\boldsymbol{K}][\boldsymbol{U}]_{i}=\left[\boldsymbol{P}_{e f f}\right]_{i}} \\
{[\boldsymbol{M}][\ddot{\boldsymbol{U}}]_{i+1}+[\boldsymbol{C}][\dot{\boldsymbol{U}}]_{i+1}+[\boldsymbol{K}][\boldsymbol{U}]_{i+1}=\left[\boldsymbol{P}_{\text {eff }}\right]_{i+1}}
\end{array} .\right.
$$



Fig. 1 Discrete diagram of system response

In Eq. (5), it is assumed that the velocity of the system at time $i+1$ depends on the acceleration change from time $i$ to time $i+1$, while the displacement at time $i+1$ depends on the velocity change from time $\mathrm{i}$ to time $i+1$, as shown in Eq. (6):

$\left\{\begin{array}{l}\dot{U}_{i+1}=\dot{U}_{i}+\int_{t_{i}}^{t_{i+1}} \ddot{U}(\tau) d \tau \\ U_{i+1}=U_{i}+\int_{t_{i}}^{t_{i+1}} \dot{U}(\tau) d \tau\end{array}\right.$,

where, $\ddot{U}(\tau)$ is the change of acceleration in time $i$ and $i+1 . U(\tau)$ is the change of speed in time $i$ and time $i+1$.

In this paper, the average acceleration hypothesis is adopted, that is, the acceleration is constant in the time interval between time $i$ and time $i+1$, the velocity changes linearly, and the displacement changes as a quadratic parabola [33]. Then Eq. (6) can be rewritten as Eq. (7) :

$$
\left\{\begin{array}{l}
\dot{U}_{i+1}=\dot{U}_{i}+\frac{\Delta t}{2}\left(\ddot{U}_{i+1}+\ddot{U}_{i}\right) \\
U_{i+1}=U_{i}+\dot{U} \Delta t+\frac{(\Delta t)^{2}}{4}\left(\ddot{U}_{i+1}+\ddot{U}_{i}\right)
\end{array},\right.
$$

where $\Delta t$ is the time interval between time $i$ and time $i+1$.

In Eq. (7), although the average acceleration method is unconditionally stable, this paper adopts the equal step method, and the time interval is taken as $0.02 \mathrm{~s}$. Through the second equation in Eq. (7) and Eq. (5), the system reaction can be solved step by step.

\section{Dynamic characteristics of base isolated structure}

In this paper, the office building of a base isolated structure in China is taken as the research object. Its structural form is a typical multi-story reinforced concrete frame structure, as shown in Fig. 2. The upper frame structure has six floors. The first floor is $4.20 \mathrm{~m}$ high, the second floor to the fifth floor is $3.60 \mathrm{~m}$ high, the sixth floor is $3.00 \mathrm{~m}$ high, the total height is $21.60 \mathrm{~m}$, the length is $58.50 \mathrm{~m}$, and the width is $17.10 \mathrm{~m}$. Its plane layout is shown in Fig. 3(a). The safety grade of the building structure is 


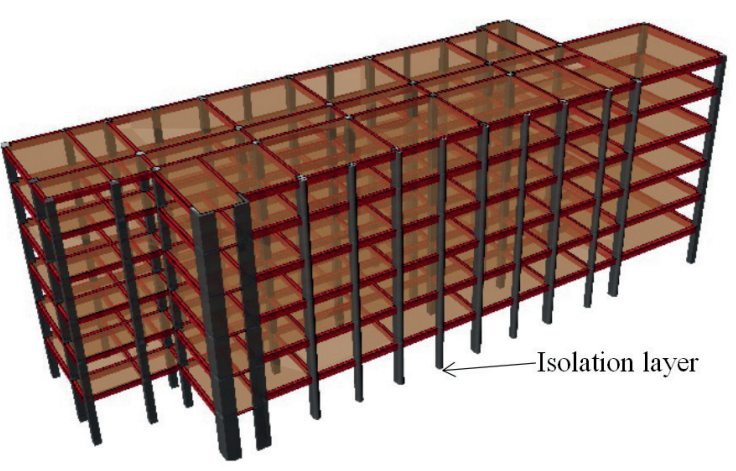

Fig. 2 Six story base isolated structure

grade II, the design service life is 50 years, and the seismic fortification intensity is grade 8 . The design is based on the Chinese code.

The nonlinear finite element model of base isolated structure is established by using OpenSEES platform (v2.4.5). The fiber beam column element based on the flexibility method is used to simulate the nonlinear behavior of the frame structure, and the constitutive relationship of the confined concrete is based on the Mander-Confirmed model [34] (Table 1), and the steel is based on the GiufreMenegotto-Pinto model [35]. The damping ratio of superstructure is 0.05 . The fiber beam column element model is divided into several sections through the integration points along the longitudinal direction of the element. The section where each integration point is located is divided into several fiber bundles along the vertical and horizontal direction of the section (Fig. 3(b)). Each fiber bundle can be defined as different materials. According to the uniaxial stressstrain relationship of the fiber bundle on the section, the force deformation relationship of the section is obtained by integrating the fiber bundle along the axis of the element. The fiber beam column element should satisfy the following assumptions: a) Plane section assumption. b) There was no relative slip between the fiber bundles. c) Torsion is linear elastic and uncoupled with axial force and bending moment.
The isolation story of the structure is located below the bottom column. Thirty one natural rubber bearings are used for the isolation story, and the lateral stiffness of the bearing is $1.18 \mathrm{kN} / \mathrm{mm}$ [1], as shown in Fig. 3(c). The finite element model ignores the height of the isolation bearing and uses zero length element to simulate the mechanical properties of the bearing (Table 2).



(a)

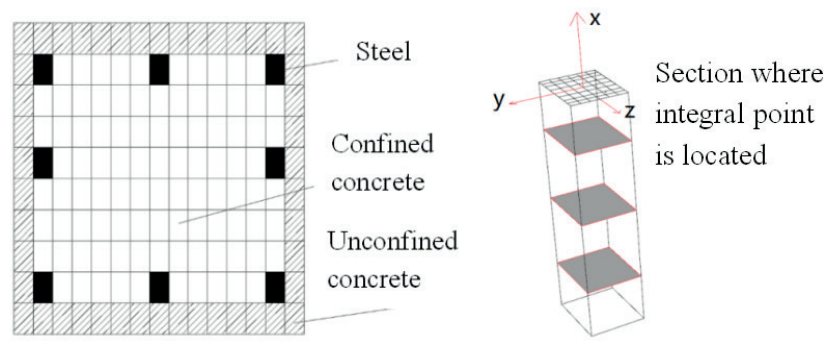

(b)

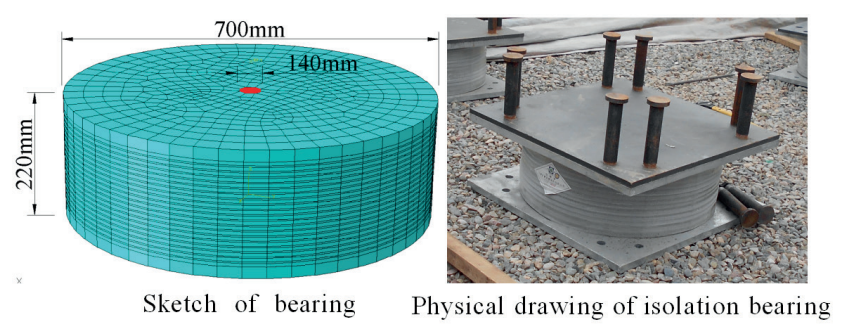

(c)

Fig. 3 Plane of isolation story and bearings (mm), (a) Plane of isolation story, (b) Fiber beam element, (c) Bearings

Table 1 Concrete material parameters

\begin{tabular}{|c|c|c|c|c|c|c|}
\hline & $\begin{array}{l}\text { Elastic modulus } \\
\qquad(\mathrm{MPa})\end{array}$ & $\begin{array}{c}\text { Maximum compressive } \\
\text { stress }(\mathrm{MPa})\end{array}$ & $\begin{array}{c}\text { Maximum } \\
\text { compress-ive strain }\end{array}$ & $\begin{array}{l}\text { Ultimate stress } \\
\qquad(\mathrm{MPa})\end{array}$ & Ultimate strain & $\begin{array}{l}\text { Maximum tensile } \\
\text { stress }(\mathrm{MPa})\end{array}$ \\
\hline $\begin{array}{l}\text { Unconfined } \\
\text { concrete }\end{array}$ & $3.25 \times 10^{4}$ & -40.00 & -0.0020 & -7.95 & -0.0090 & 3.92 \\
\hline $\begin{array}{l}\text { Confined } \\
\text { concrete }\end{array}$ & $3.25 \times 10^{4}$ & $-44.15 \sim-48.38$ & $-0.0036 \sim-0.0041$ & $-22.08 \sim-24.19$ & $-0.0135 \sim-0.0275$ & 3.92 \\
\hline
\end{tabular}

Table 2 Parameters of isolation bearing by manufacturer

\begin{tabular}{|c|c|c|c|c|c|c|}
\hline Diameter & $\begin{array}{l}\text { Vertical stiffness } \\
(\mathrm{kN} / \mathrm{mm})\end{array}$ & $\begin{array}{c}\text { Yield strength } \\
(\mathrm{kN})\end{array}$ & $\begin{array}{l}\text { Horizontal stiffness } \\
\text { before yield }(\mathrm{kN} / \mathrm{m})\end{array}$ & $\begin{array}{l}\text { Horizontal stiffness } \\
\text { after yield }(\mathrm{kN} / \mathrm{m})\end{array}$ & $\begin{array}{l}\text { Equivalent horizontal } \\
\text { stiffness }(\mathrm{kN} / \mathrm{m})\end{array}$ & $\begin{array}{c}\text { Equivalent damping } \\
\text { ratio }\end{array}$ \\
\hline$\phi 700$ & 3030 & 123.1 & 11800 & 1180 & 1988 & 0.275 \\
\hline
\end{tabular}




\subsection{Inherent dynamic characteristics of structure}

The isolation bearing has a small horizontal lateral stiffness, which makes the horizontal displacement of the first mode of the structure mainly concentrated in the isolation story, while the deformation of the upper structure is relatively small, in where achieving the effect of isolation.

In addition, the period of the isolated structure is often larger and the frequency is smaller compared with the non-isolated frame structure (fixed base structure), which exceeds the excitation frequency of the non near-fault earthquake action and reduces the response of the structure. Fig. 4 shows the $12^{\text {th }}$ natural frequency of vibration of isolated and non-isolated structures. It can be seen from Fig. 4 that, compared with the non-isolated frame structure, the periods of each stage of the isolated structure are significantly prolonged and the frequency is significantly reduced, among which the first three stages are increased by $117.90 \%, 110.00 \%$ and $127.81 \%$, respectively.

\subsection{Dynamic response}

In order to explore the dynamic response characteristics of base isolated structure under the action of earthquake, and compare the distinction between the dynamic response under the action of far-fault earthquake and near-fault earthquake. Three records of natural far-fault acceleration and three records of near-fault acceleration are selected, and the amplitude modulated records are used as the excitation. The nonlinear dynamic time history analysis of the finite element model of non-isolated structure and base isolated structure is carried out by using the above method. At present, scholars have not reached a unified understanding of the fault distance of the near-fault condition. Taking the distance of $60 \mathrm{~km}$ from the fault as the boundary [36], they distinguish the near-fault seismic wave and the farfault seismic wave [21]. The three records of far-fault earthquake acceleration are Trinidad, Eagle Lake and Sparks.

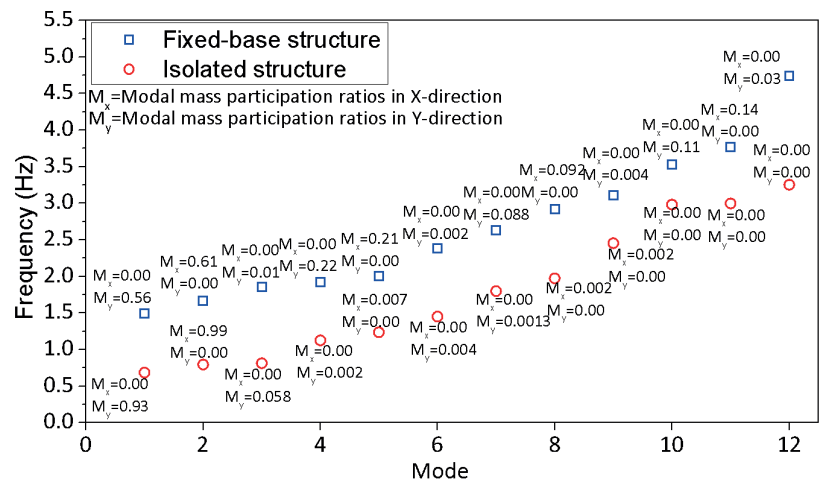

Fig. 4 Frequencies of structures
The distance from the corresponding observation stations to the fault is $76.26 \mathrm{~km}, 118.07 \mathrm{~km}$ and $60.07 \mathrm{~km}$ respectively. The three records of far-fault vibration are non-pulse type. The three near-fault seismic records are Imperial Valley, Northridge and Iwate, respectively. The distances from the corresponding observation stations to the faults are $17.94 \mathrm{~km}, 8.66 \mathrm{~km}$ and $16.96 \mathrm{~km}$, respectively. In order to unify the PGA recorded by the six acceleration records, the amplitude of PGA is adjusted to $400 \mathrm{~cm} / \mathrm{s}^{2}$ according to the 8-degree rare earthquake in the Chinese seismic code.

The specific amplitude modulation coefficient is shown in Table 3 and Fig. 5 shows the elastic acceleration response spectra of near-fault and far-fault earthquake records with damping ratio of $5 \%$. It can be seen that the discreteness of response spectrum reflects the accidental uncertainty of ground motion.

Tables 4 and 5 display the peak values of each response of the top node of the structure under the far-fault and near-fault seismic actions, as well as the peak values of the

Table 3 Factor of acceleration amplitude modulation

\begin{tabular}{ccccccc}
\hline & \multicolumn{3}{c}{ far-fault } & \multicolumn{3}{c}{ near-fault } \\
Waves & Trinidad & $\begin{array}{c}\text { Eagle } \\
\text { Lake }\end{array}$ & Sparks & $\begin{array}{c}\text { Imperial } \\
\text { Valley }\end{array}$ & Northridge & Iwate \\
\hline Factor & 2.89 & 11.66 & 2.36 & 1.83 & 0.69 & 1.59 \\
\hline
\end{tabular}

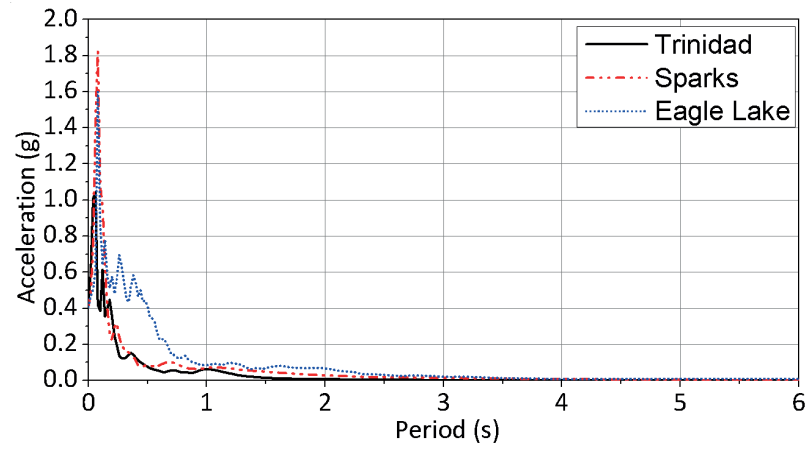

(a)

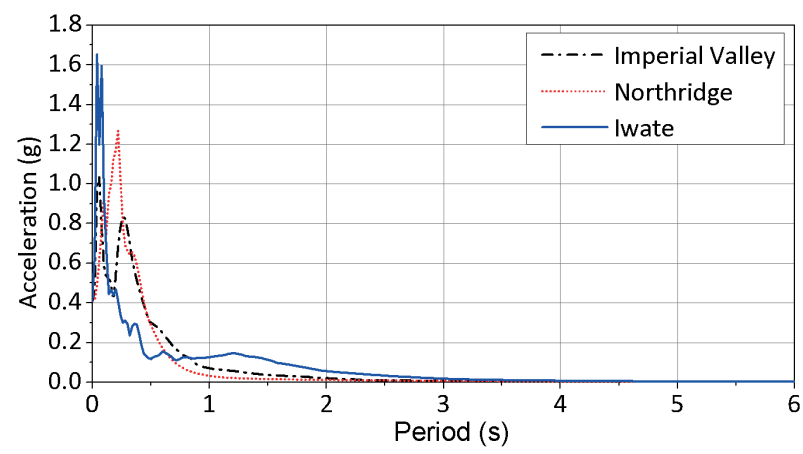

(b)

Fig. 5 Acceleration response spectra, (a) Far-fault earthquake records, (b) Near-fault earthquake records 
response of the isolated and non-isolated structures (fixed base structure). It can be seen that the maximum acceleration of the top node of the base isolated structure is significantly reduced compared with the non-isolated structure under the condition of far-fault or near-fault earthquake. Under three far-fault seismic actions of Trinidad, Eagle Lake and Sparks, the maximum acceleration of the top node decreases by $49.12 \%, 9.99 \%$ and $33.53 \%$, respectively. The maximum acceleration of the top node decreased by $36.84 \%, 26.36 \%$ and $46.20 \%$ respectively under the three near-fault seismic actions of Imperial Valley, Northridge and Iwate. Due to the large horizontal displacement of the isolation story, the response of the whole superstructure to horizontal displacement will be increased. Under the action of Trinidad, Eagle Lake and Sparks, the maximum displacement of the top node increases by $54.28 \%, 390.00 \%$ and $219.51 \%$ respectively. Under the three near-fault seismic actions of Imperial
Valley, Northridge and Iwate, the maximum displacements of the top node increased by $246.37 \%, 198.53 \%$ and $116.78 \%$, respectively.

Fig. 6 shows the change of the maximum story drift of each story under six seismic excitations. It can be seen from Fig. 6 that in the selected ground motion records, no matter the near-fault earthquake excitation or the far-fault earthquake excitation, the displacement angle response of the first story of the structure significantly decreases, and the maximum value of the story drift response of each story correspondingly decreases. Under three farfault seismic actions of Trinidad, Eagle Lake and Sparks, the maximum value of story drift decreased by $73.47 \%$, $42.86 \%$ and $44.65 \%$, respectively. The maximum values of story drift between the lower stories under the action of three near-fault earthquake waves, Imperial Valley, Northridge and Iwate, decreased by $64.67 \%, 69.66 \%$ and $70.90 \%$, respectively.

Table 4 Maximum response of structure under far-fault earthquake

\begin{tabular}{|c|c|c|c|c|}
\hline & Earthquake wave & Fixed base structure & Isolated structure & Change rate \\
\hline \multirow{3}{*}{ Acceleration $\left(\mathrm{mm} / \mathrm{s}^{2}\right)$} & Trinidad & 9702.90 & 4936.90 & $-49.12 \%$ \\
\hline & Eagle Lake & 4943.00 & 4448.99 & $-9.99 \%$ \\
\hline & Sparks & 6416.62 & 4265.28 & $-33.53 \%$ \\
\hline \multirow{3}{*}{ Velocity $(\mathrm{mm} / \mathrm{s})$} & Trinidad & 592.27 & 389.36 & $-34.26 \%$ \\
\hline & Eagle Lake & 106.78 & 140.19 & $31.29 \%$ \\
\hline & Sparks & 299.35 & 413.51 & $38.14 \%$ \\
\hline \multirow{3}{*}{ Displacement (mm) } & Trinidad & 37.80 & 58.32 & $54.28 \%$ \\
\hline & Eagle Lake & 4.50 & 22.05 & $390.00 \%$ \\
\hline & Sparks & 25.12 & 80.26 & $219.51 \%$ \\
\hline \multirow{3}{*}{ Story drift $\left(10^{-3}\right)$} & Trinidad & 2.45 & 0.65 & $-73.47 \%$ \\
\hline & Eagle Lake & 0.42 & 0.24 & $-42.86 \%$ \\
\hline & Sparks & 1.59 & 0.88 & $-44.65 \%$ \\
\hline
\end{tabular}

Table 5 Maximum response of structure under near-fault earthquake

\begin{tabular}{|c|c|c|c|c|}
\hline & Earthquake wave & Fixed base structure & Isolated structure & Change rate \\
\hline \multirow{3}{*}{ Acceleration $\left(\mathrm{mm} / \mathrm{s}^{2}\right)$} & Imperial Valley & 8230.27 & 5198.30 & $-36.84 \%$ \\
\hline & Northridge & 8612.40 & 6342.40 & $-26.36 \%$ \\
\hline & Iwate & 8508.99 & 4577.37 & $-46.20 \%$ \\
\hline \multirow{3}{*}{ Velocity $(\mathrm{mm} / \mathrm{s})$} & Imperial Valley & 511.64 & 682.24 & $33.34 \%$ \\
\hline & Northridge & 672.20 & 950.31 & $41.37 \%$ \\
\hline & Iwate & 688.21 & 615.16 & $-10.61 \%$ \\
\hline \multirow{3}{*}{ Displacement (mm) } & Imperial Valley & 50.01 & 173.22 & $246.37 \%$ \\
\hline & Northridge & 60.04 & 179.24 & $198.53 \%$ \\
\hline & Iwate & 55.20 & 119.66 & $116.78 \%$ \\
\hline \multirow{3}{*}{ Story drift $\left(10^{-3}\right)$} & Imperial Valley & 3.34 & 1.18 & $-64.67 \%$ \\
\hline & Northridge & 4.12 & 1.25 & $-69.66 \%$ \\
\hline & Iwate & 3.78 & 1.10 & $-70.90 \%$ \\
\hline
\end{tabular}




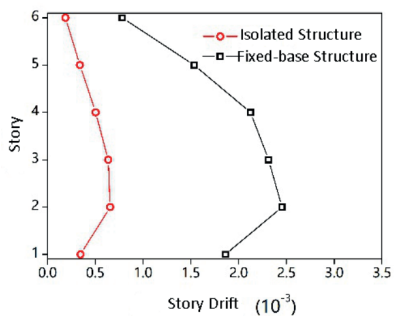

(a)

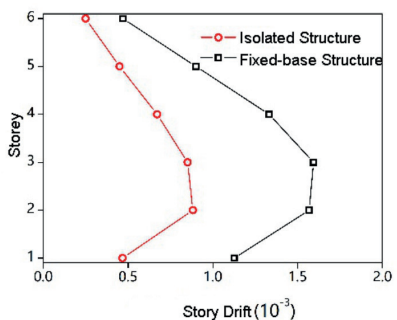

(c)

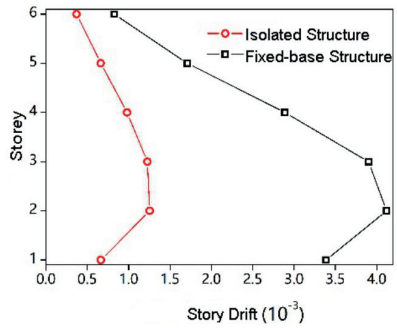

(e)

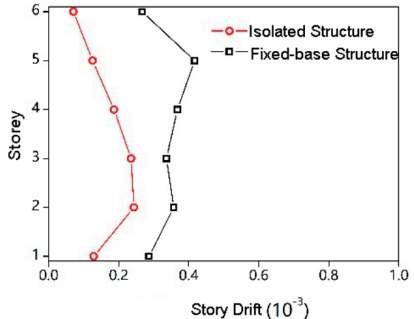

(b)

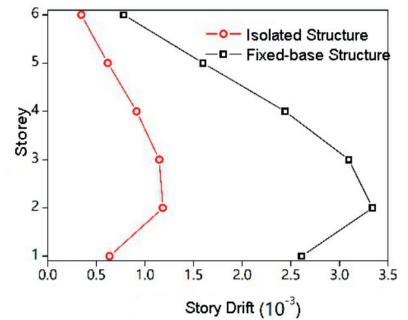

(d)

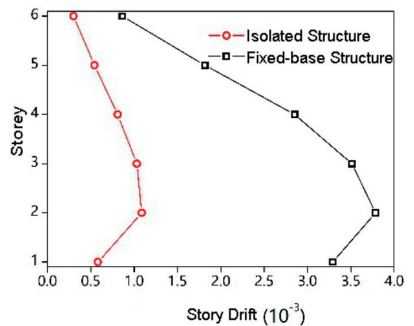

(f)

Fig. 6 Maximum story drift of each story under seismic action, (a) Trinidad, (b) Imperial Valley, (c) Eagle Lake, (d) Northridge, (e) Sparks, (f) Iwate

The deformation of the isolation structure is effectively controlled under the excitation of near-fault and far-fault earthquake, and the story drift is significantly reduced. However, the maximum value of the story drift of the base isolated structure in the near-fault condition is obviously larger than that in the far-fault condition. This kind of change is noteworthy. When the base isolated structure encounters ground motion with greater intensity than the fortification, the story drift between the lower stories may become larger under the near-fault condition, which is extremely unfavorable. Therefore, in the research and application of base isolated structure, it is significant to consider the near-fault earthquake action. In addition, in some previous studies on isolated structures, it may not be accurate to assume that the superstructure is linear elastic under near-fault conditions. Therefore, under the influence of near-fault conditions, it is necessary to consider the nonlinearity of superstructure.

The lateral stiffness of the isolation story is smaller compared with the superstructure. Under the action of nearfault earthquake, there may be large lateral displacement

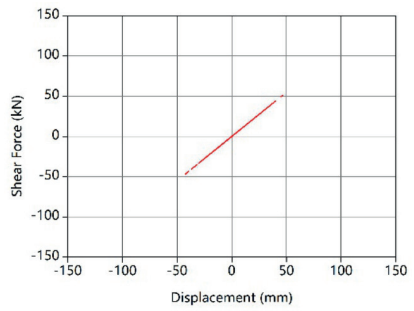

(a)

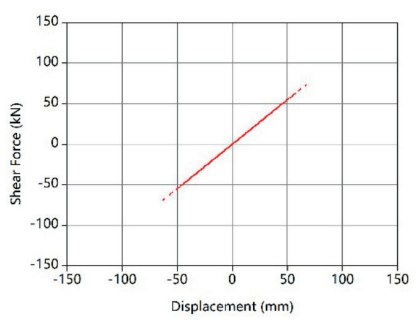

(c)



(e)

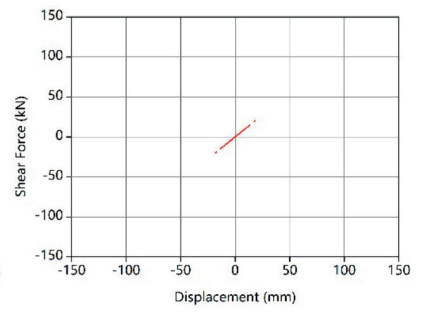

(b)

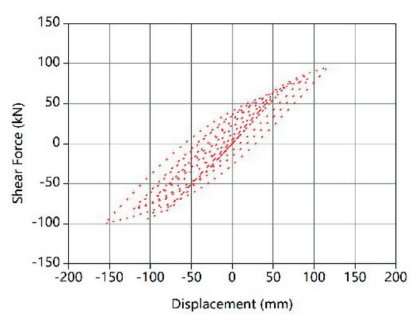

(d)

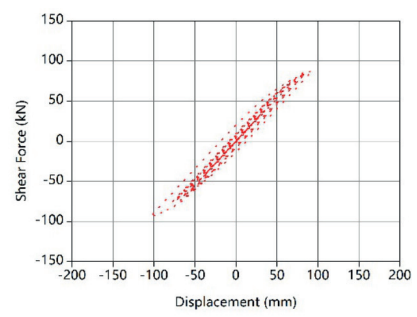

(f)
Fig. 7 Hysteretic curve of rubber bearing under earthquake, (a) Trinidad, (b)Imperial Valley, (c) Eagle Lake, (d) Northridge, (e)Sparks, (f) Iwate

and large shear deformation of rubber bearing, which may lead to damage or even damage of the bearing. Fig. 7 demonstrates the force-displacement hysteretic curves of the rubber bearings under the selected 6 earthquake motions. It can be seen from Fig. 7(a), (b) and (c) that under the three far-fault seismic actions of Trinidad, Eagle Lake and Sparks, the relationship between the force-displacement of the isolation bearing is basically linear, and the bearing is basically in an elastic state. However, under the three near-fault seismic actions of Imperial Valley, Northridge and Iwate with the same amplitude modulation of PGA, the bearing has large lateral displacement, and the bearing no longer maintains the elastic stage but enters into the plastic stage. It can be seen in Fig. 7(d), (e) and (f) that the force-displacement curve of rubber isolation bearing is no longer linear, and there is obvious hysteresis.

Even if enough gap can be reserved between the isolation story and the adjacent structure through design and analysis to avoid the collision under the earthquake action, the damage of rubber isolation bearing itself cannot be eliminated and reduced. The damage of isolation bearing 
cannot be ignored. Therefore, in order to better evaluate the performance of base isolated structure under near-fault earthquake, it is necessary to fully study the bearing damage and failure.

\section{Seismic fragility analysis}

The earthquake is unpredictable. In order to evaluate the earthquake risk that engineering structure may suffer damage in the earthquake, and guide the seismic design and the damage assessment of the structure after the earthquake, it is necessary to establish the corresponding probability model. In the seismic risk analysis of structures, it is very important to establish fragility model. There are 50 natural near-fault earthquake records were selected and amplitude modulated, and the ground motion records obtained after amplitude modulation were used as excitation to carry out nonlinear dynamic time-history analysis of base isolated structures. Table 6 shows the main information of the selected near-fault earthquake records.

In this paper, $0.1 \mathrm{~g}$ is used as the interval for amplitude modulation of the selected acceleration records. The recorded peak values of each ground motion acceleration are $0.1 \mathrm{~g}, 0.2 \mathrm{~g}, 0.3 \mathrm{~g}, 0.4 \mathrm{~g}, 0.5 \mathrm{~g}, 0.6 \mathrm{~g}, 0.7 \mathrm{~g}, 0.8 \mathrm{~g}$, $0.9 \mathrm{~g}$ and $1.0 \mathrm{~g}$, respectively. A total of 500 ground motion samples are obtained. Fig. 8(a) and (b) respectively display the IDA curve of the maximum displacement of the rubber bearing and the IDA curve of the maximum story drift of the superstructure under the actions of various earthquake waves. With the increase of the peak acceleration recorded by the ground motion, the maximum response values of the displacement and the story drift of the rubber isolation bearing are on the rise. But the variation of ground motion has a great influence on the performance of rubber bearings and superstructure. When the PGA is less than $0.2 \mathrm{~g}$, the dispersion of the maximum response values of the horizontal lateral displacement of the rubber bearing and the story drift of the superstructure under different ground motion records is relatively small, and the dynamic response of the system at this stage is relatively insensitive to the variation of the spectrum characteristics of the ground motion records. With the increase of ground motion intensity, the discreteness of horizontal lateral displacement of isolation bearing and the maximum response of story drift of superstructure shows an overall growth trend, and the sensitivity of dynamic response of the system to the spectral characteristics of ground motion recording increases. Fig. 9(a) and (b) respectively show

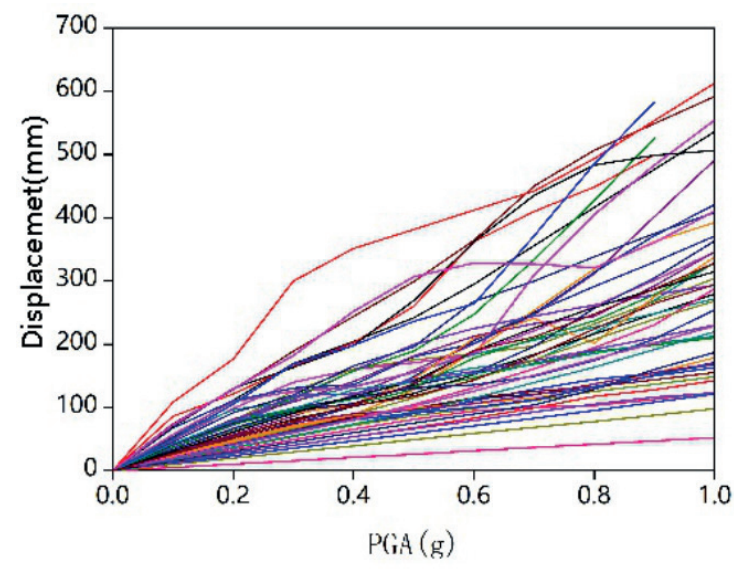

(a)

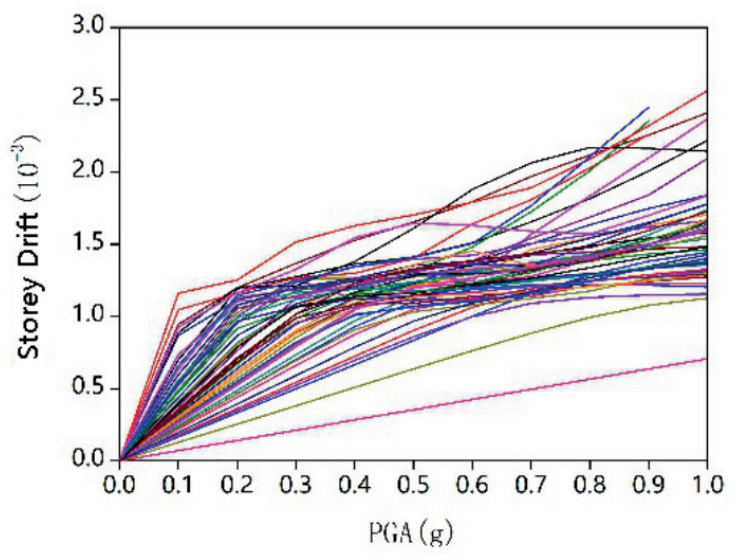

(a)

Fig. 8 IDA curve, (a) IDA curve of rubber isolation bearing, (b) IDA curve of story drift

the standard deviation of the maximum bearing displacement and the story drift under the corresponding seismic intensity. When the PGA is small, the lateral displacement of the bearing and the increase of the story drift between the stories of the superstructure are basically linear with PGA, and the system is basically in linear elasticity. When the local vibration intensity increases to a certain value, the superstructure and support will enter into a non-linear state under most of the earthquake excitation.

In order to better evaluate the performance of base isolated structure in earthquake action, this paper uses the results of incremental dynamic analysis (IDA) to establish the fragility curve of base isolated structure by two methods: one is based on Probabilistic Seismic Demand Analysis (PSDA). The other is to use the Engineering Demand Parameter (EDP) as the probability calculation parameter to calculate the probability that the structure or component reaches or exceeds a certain limit state under the specific seismic intensity, so as to establish the fragility curve. 
Table 6 Near-fault earthquake records

\begin{tabular}{|c|c|c|c|c|c|c|}
\hline No. & Earthquake Record & Station & PGA (g) & $\mathrm{PGV}(\mathrm{cm} / \mathrm{s})$ & $\mathrm{Mw}$ & EpiD $(\mathrm{km})$ \\
\hline 1 & Managua, Nicaragua-01 & Managua, ESSO & 0.35 & 28.41 & 6.24 & 5.68 \\
\hline 2 & Managua, Nicaragua-02 & Managua, ESSO & 0.23 & 22.00 & 5.20 & 5.68 \\
\hline 3 & Imperial Valley-06 & Agrarias & 0.24 & 38.37 & 6.53 & 2.62 \\
\hline 4 & Imperial Valley-06 & Bonds Corner & 0.69 & 49.56 & 6.53 & 6.19 \\
\hline 5 & Imperial Valley-06 & Calexico Fire Station & 0.24 & 21.31 & 6.53 & 17.66 \\
\hline 6 & Imperial Valley-06 & El Centro Array \#11 & 0.37 & 40.77 & 6.53 & 29.53 \\
\hline 7 & Imperial Valley-06 & El Centro Array \#12 & 0.14 & 22.27 & 6.53 & 31.99 \\
\hline 8 & Northridge-01 & Arleta-Nordhoff Fire Sta & 0.33 & 29.29 & 6.69 & 11.10 \\
\hline 9 & Northridge- 01 & Beverly Hills-12520 Mulhol & 0.54 & 30.38 & 6.69 & 16.27 \\
\hline 10 & Northridge- 01 & Beverly Hills-14145 Mulhol & 0.44 & 59.81 & 6.69 & 13.39 \\
\hline 11 & Northridge-01 & Big Tujunga, Angeles Nat F & 0.21 & 10.91 & 6.69 & 31.55 \\
\hline 12 & Northridge-01 & Burban-Howard Rd & 0.14 & 9.27 & 6.69 & 23.18 \\
\hline 13 & Northridge- 01 & Canoga Park-Topanga Can & 0.36 & 48.58 & 6.69 & 4.85 \\
\hline 14 & Northridge-01 & Canyon Country-W Lost Cany & 0.40 & 45.16 & 6.69 & 26.49 \\
\hline 15 & Northridge-01 & Jensen Filter Plant Generator Building & 0.76 & 68.37 & 6.69 & 13.00 \\
\hline 16 & Northridge- 01 & LA-Sepulveda VA Hospital & 0.75 & 72.48 & 6.69 & 8.48 \\
\hline 17 & Northridge-01 & LA 00 & 0.34 & 27.64 & 6.69 & 14.41 \\
\hline 18 & Northridge-01 & LA Dam & 0.35 & 67.13 & 6.69 & 11.79 \\
\hline 19 & Northridge-01 & La Crescenta-New York & 0.18 & 12.17 & 6.69 & 27.83 \\
\hline 20 & Northridge-01 & N Hollywood-Coldwater Can & 0.27 & 24.17 & 6.69 & 13.12 \\
\hline 21 & Northridge-01 & Newhall-Fire Sta & 0.65 & 86.67 & 6.69 & 20.27 \\
\hline 22 & Kobe, Japan & Nishi-Akashi & 0.47 & 39.49 & 6.90 & 8.70 \\
\hline 23 & Kobe, Japan & Takarazuka & 0.65 & 72.74 & 6.90 & 38.60 \\
\hline 24 & Kocaeli, Turkey & Arcelik & 0.17 & 31.14 & 7.51 & 53.68 \\
\hline 25 & Kocaeli, Turkey & Gebze & 0.19 & 40.77 & 7.51 & 47.03 \\
\hline 26 & Kocaeli, Turkey & Izmit & 0.19 & 33.04 & 7.51 & 5.31 \\
\hline 27 & Chi-Chi, Taiwan & CHY006 & 0.36 & 55.82 & 7.62 & 40.47 \\
\hline 28 & Chi-Chi, Taiwan & CHY010 & 0.20 & 18.50 & 7.62 & 51.22 \\
\hline 29 & Chi-Chi, Taiwan & CHY028 & 0.77 & 69.07 & 7.62 & 32.67 \\
\hline 30 & Chi-Chi, Taiwan & CHY029 & 0.27 & 36.09 & 7.62 & 39.70 \\
\hline 31 & Chi-Chi, Taiwan & CHY034 & 0.30 & 42.13 & 7.62 & 46.13 \\
\hline 32 & Chi-Chi, Taiwan & CHY035 & 0.26 & 38.23 & 7.62 & 43.90 \\
\hline 33 & Chi-Chi, Taiwan & CHY036 & 0.25 & 43.74 & 7.62 & 44.02 \\
\hline 34 & Chi-Chi, Taiwan & CHY041 & 0.50 & 30.51 & 7.62 & 51.15 \\
\hline 35 & Chi-Chi, Taiwan & CHY080 & 0.83 & 96.29 & 7.62 & 31.65 \\
\hline 36 & Duzce, Turkey & Bolu & 0.78 & 62.90 & 7.14 & 41.27 \\
\hline 37 & Duzce, Turkey & Duzce & 0.43 & 78.70 & 7.14 & 1.61 \\
\hline 38 & Iwate & AKT023 & 0.39 & 20.52 & 6.90 & 19.22 \\
\hline 39 & Iwate & AKTH04 & 1.77 & 63.73 & 6.90 & 21.26 \\
\hline 40 & Iwate & IWT010 & 0.27 & 24.87 & 6.90 & 23.17 \\
\hline 41 & Iwate & IWT011 & 0.19 & 17.92 & 6.90 & 27.09 \\
\hline 42 & Iwate & IWTH24 & 0.47 & 33.11 & 6.90 & 22.14 \\
\hline 43 & Iwate & IWTH25 & 1.35 & 64.88 & 6.90 & 2.52 \\
\hline 44 & Iwate & IWTH26 & 1.03 & 50.68 & 6.90 & 12.88 \\
\hline 45 & Iwate & MYG005 & 0.44 & 59.06 & 6.90 & 32.09 \\
\hline 46 & Iwate & MYGH02 & 0.25 & 17.36 & 6.90 & 27.14 \\
\hline 47 & Iwate & Kitakami Yanagiharach & 0.20 & 8.90 & 6.90 & 35.62 \\
\hline 48 & Iwate & Mizusawaku Interior O Ganecho & 0.31 & 26.57 & 6.90 & 25.34 \\
\hline 49 & Iwate & Kurihara City & 0.59 & 48.58 & 6.90 & 24.77 \\
\hline 50 & Duzce, Turkey & IRIGM 496 & 1.00 & 40.04 & 7.14 & 24.31 \\
\hline
\end{tabular}




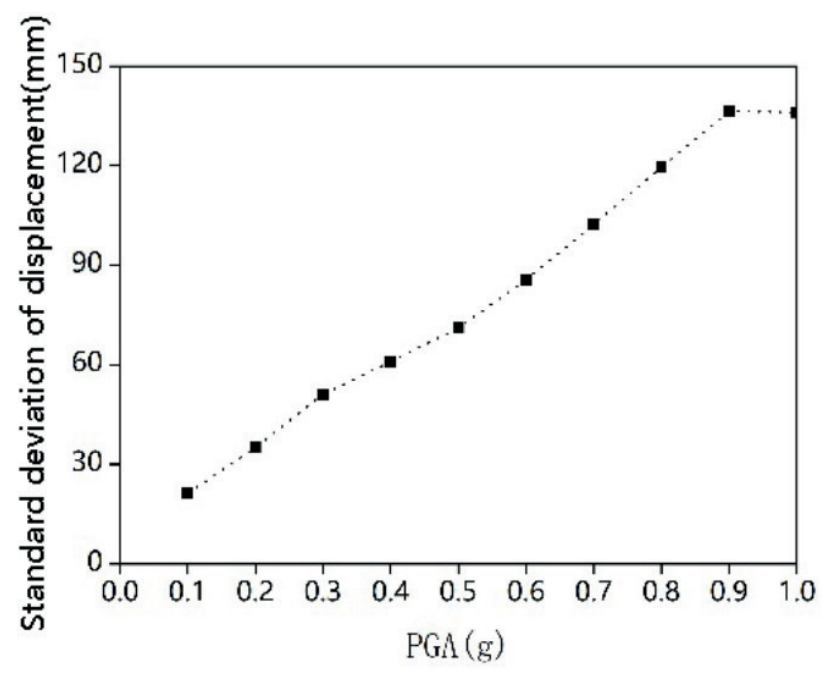

(a)

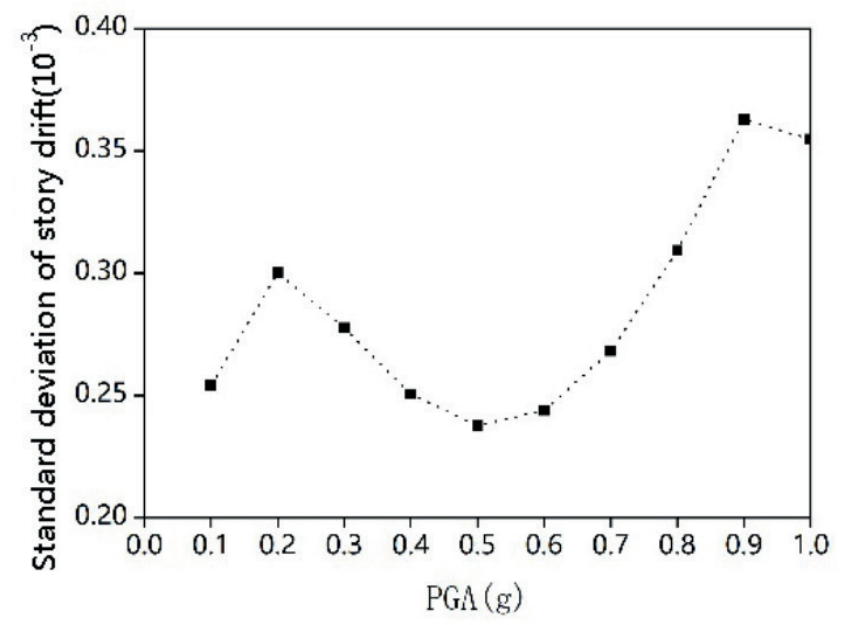

(b)

Fig. 9 Trend of standard deviation, (a) Rubber isolation bearing, (b Story drift

In reference [37], the limit state of the isolated structure is divided into four grades, and the macroscopic description of the corresponding grade and the recommended limit value of the story drift are given (as shown in Table 7). In this paper, the limit value in Table 7 is used as one of the indicators for the establishment of fragility model. When the quantitative index is less than LS1, the structure is basically intact. When LS1 is exceeded, the structure is slightly damaged. When LS2 is exceeded, the structure will be damaged moderately. When LS3 is exceeded, the structure is seriously damaged. When LS4 is exceeded, the structure collapses.

Because of the importance of isolation bearing in the whole system, the shear deformation of isolation bearing is another index of fragility model. The limit states (DS1, DS2, DS3, DS4) of four isolation bearings are defined to correspond to $100 \%, 150 \%, 200 \%$ and $250 \%$ of shear deformation of bearings respectively. In the establishment of structural fragility model, the commonly used seismic intensity index mainly includes spectrum index and peak index. In this paper, the peak recorded acceleration (PGA) of the peak index is used as the strength index.

\subsection{Fragility model based on PSDA}

The fragility curve usually reflects the relationship between the seismic intensity parameters and the structural performance evaluation parameters, and the expression can be written as Eq. (8):

Fragility $=P(L S \mid I M)$,

where, $L S$ is a specific limit state or damage state of the structure or component. $I M$ is a specific ground motion intensity. The probability expression of structural seismic fragility can be rewritten as Eq. (9):

$P\left(L S_{i} \mid I M=i m\right)=P\left(D M \geq d m_{i} \mid I M=i m\right)$,

where, $L S_{i}$ is a specific limit state. $i m$ is a specific ground motion intensity. $d m_{i}$ is the limit value corresponding to the damage index. Assuming that the ground motion intensity index $I M$ and the structural damage index $D M$ obey the lognormal distribution, Eq. (9) can be expressed as Eq. (10):

$$
\begin{aligned}
& P\left(D M \geq d m_{i} \mid I M=i m\right)=1-P\left(D M<d m_{i} \mid I M=i m\right) \\
& =1-\Phi\left[\frac{\ln \left(d m_{i}\right)-\mu_{\ln (D M \mid I M=i m)}}{\sigma_{\ln (D M \mid I M=i m)}}\right],
\end{aligned}
$$

where, $\mu_{1 n}(D M \mid I M=i m)$ and $\sigma_{1 n}(D M \mid I M=i m)$ are mean value and standard deviation respectively. $\Phi[x]$ is standard normal cumulative distribution function.

\begin{tabular}{|c|c|c|c|c|}
\hline Structural state & Operational & Immediate occupancy & Life safety & Collapse prevention \\
\hline \multirow{2}{*}{ Quantitative index limit } & LS1 & LS2 & LS3 & LS4 \\
\hline & $1 / 550$ & $1 / 250$ & $1 / 100$ & $1 / 60$ \\
\hline Macroscopical description & $\begin{array}{c}\text { The superstructure and } \\
\text { the isolation device are } \\
\text { undamaged and do not } \\
\text { need to be repaired }\end{array}$ & $\begin{array}{c}\text { The superstructure is } \\
\text { slightly damaged, and } \\
\text { the isolation device is not } \\
\text { damaged }\end{array}$ & $\begin{array}{l}\text { Slight or moderate damage } \\
\text { to superstructure and slight } \\
\text { damage to isolation bearing }\end{array}$ & $\begin{array}{c}\text { Medium or more severe } \\
\text { damage of superstructure } \\
\text { and more severe damage of } \\
\text { isolation bearing }\end{array}$ \\
\hline
\end{tabular}

Table 7 Quantitative index of story drift in limit state of isolated structure 
The relationship between ground motion intensity $I M$ and structural response $D M$ is power exponential regression:

$\ln (D M)=a \ln (I M)+b$,

where $a$ and $b$ are constants.

It can be seen from Eq. (11) that $\ln (D M)$ and $\ln (I M)$ satisfy the linear relationship, then, substituting Eq. (11) into Eq. (9), Eq. (12) can be obtained.

$$
P\left(D M \geq d m_{i} \mid I M=i m\right)=\Phi\left[\frac{a \ln (I M)+b-\ln \left(d m_{i}\right)}{\sigma_{\ln (D M \mid I M=i m)}}\right]
$$

The standard deviation in Eq. (12) can be calculated by Eq. (13):

$$
\sigma_{\ln (D M \mid I M=i m)}=\sqrt{\frac{1}{N-2} \sum_{i=1}^{N}\left[\ln (D M)-\mu_{\ln (D M \mid I M=i m)}\right]^{2}} .
$$

The nonlinear dynamic time-history analysis of the structure is carried out by taking all the seismic record samples as the excitation, and the maximum response and the corresponding seismic intensity are taken as logarithm, and the linear regression is carried out to get the Eq. (11). Fig. 10 shows the probabilistic demand earthquake regression model of the rubber bearing deformation and the upper structure inter-story drift, respectively. The corresponding regression equations are given in Table 8 .

\subsection{Fragility model based on EDP criterion}

The Engineering Demand Parameter (EDP) is used as the probability calculation parameter to calculate the probability that the structure or component reaches or exceeds a certain limit state under a given earthquake intensity. That is to say, under the given earthquake intensity, the probability that the seismic demand of structural or component engineering demand parameter is greater than the seismic capacity can be calculated, and the expression of fragility probability can be written as Eq. (14):

$$
P(E D P \mid I M)=P\left(E D P_{d} \geq E D P_{c} \mid I M=i m\right),
$$

where, $E D P_{d}$ is the seismic demand of the structure or component. $E D P_{c}$ is the seismic capacity of the structure or component.

In Eq. (14), the seismic demand can be expressed by the maximum response of the structure calculated by each nonlinear dynamic time history analysis. In this paper, the seismic capacity can be expressed by the damage index limits of each limit state selected above. In order to quantitatively calculate the probability expression of Eq. (14), it can be rewritten as Eq. (15):

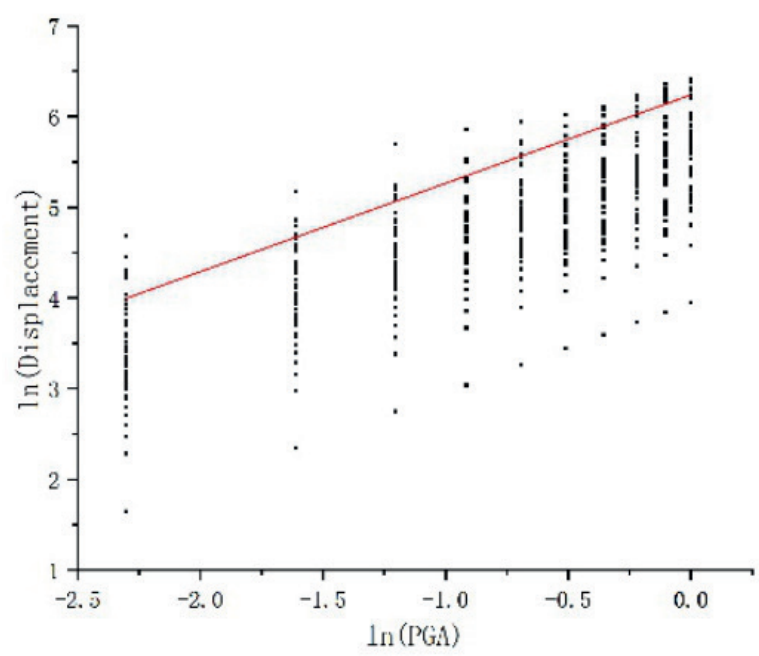

(a)

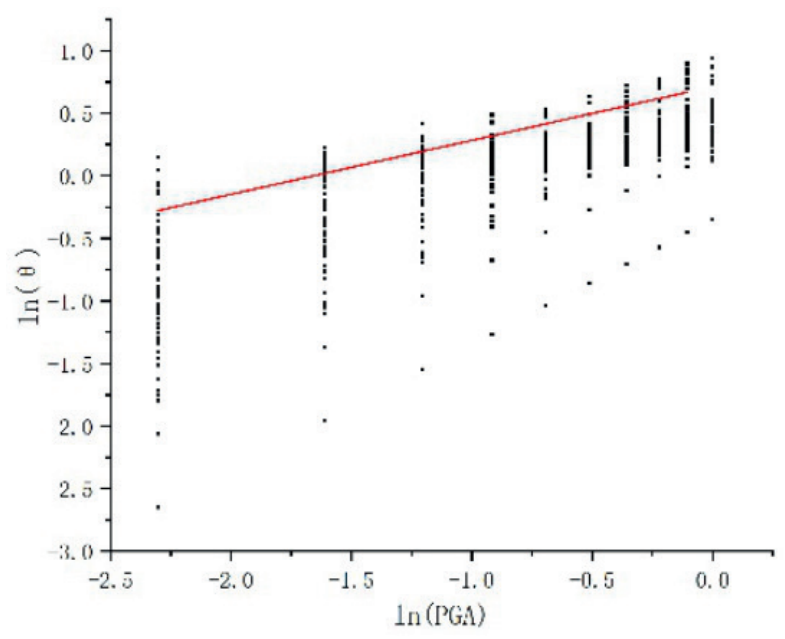

(b)

Fig. 10 Probability demand earthquake regression model,

(a) Displacement of rubber isolation bearing, (b) Story drift

Table 8 Probability demand earthquake regression equation

\begin{tabular}{lcc}
\hline Index parameter & Regression equation & Standard deviation \\
\hline $\begin{array}{l}\text { Displacement of } \\
\text { rubber bearing }\end{array}$ & $\ln (u)=0.97 \ln (I M)+6.24$ & 0.39 \\
Story drift & $\ln (\theta)=0.43 \ln (I M)+0.71$ & 0.46 \\
\hline
\end{tabular}

$P(E D P \mid I M)=\frac{\sum_{i=0}^{N} F_{i}}{N}$,

where, $N$ is the number of samples of natural earthquake records selected, in this example, $N$ is taken as 50. $F_{i}$ as the limit state function of structure or component.

The above equation represents the state of the structure or component under the excitation of the $i$-th seismic record when the seismic intensity is $I M$. When the seismic demand $E D P_{d}$ is greater than the seismic capacity $E D P_{c}$, the value of $F_{i}$ is 1 , otherwise 0 , as shown in Eq. (16). 
$F_{i}=\left\{\begin{array}{l}1, \quad E D P_{d}^{i} \geq E D P_{c}^{i} \\ 0, \quad E D P_{d}^{i}<E D P_{c}^{i}\end{array}\right.$

Through Eqs. (15) and (16), a structural fragility model based on the criteria of engineering demand parameters can be established.

\subsection{Fragility analysis}

Fig. 11(a) and (b) manifest the fragility curves of base isolated structures based on Probability Seismic Demand Analysis (PSDA) and Engineering Demand Parameter (EDP) criteria, respectively. It can be seen that when the performance of the base isolated structure under the nearfault earthquake is considered comprehensively with the story drift between stories as the index. Although the near-fault earthquake will bring adverse effects to the isolated structure, the whole performance of the base isolated structure is excellent within the range of the studied ground motion (PGA is within $0.1 \mathrm{~g}-1.0 \mathrm{~g}$ ). All of them did not exceed LS3 state, i.e. the maximum damage was only moderate and no serious damage occurred.

From the fragility curve established by EDP criterion, it can be seen that the story drift index only exceeds LS1 state, and the whole base isolated structure only suffers slight damage. When PGA is less than $0.6 \mathrm{~g}$, the probability of the maximum story drift exceeding LS1 state is almost zero. When PGA is greater than $0.6 \mathrm{~g}$, the probability of the maximum story drift exceeding LS1 increases relatively significantly, but the probability is relatively small. When PGA is equal to $1.0 \mathrm{~g}$, the probability is less than $20 \%$. According to the fragility curve established based on PSDA, the whole base isolated structure may have moderate damage, but the probability of occurrence is small. When PGA reaches $1.0 \mathrm{~g}$, the probability of the maximum story drift exceeding LS2 is only $8.89 \%$. With the increase of PGA, the probability of maximum story drift exceeding LS1 increases obviously. When PGA is close to $1.0 \mathrm{~g}$, the probability of slight damage of base isolated structure is close to $60 \%$.

If the story drift is taken as the index, it can be seen that the base isolation structure performs well under the earthquake action with PGA less than $1.0 \mathrm{~g}$, and can be used continuously through minor repair or no repair after the earthquake action, which can adapt to the change trend that the earthquake disaster is dominated by the death of people to the economic loss. Since people no longer need to spend a lot of money on demolition and reconstruction, this effectively reduces the economic loss.

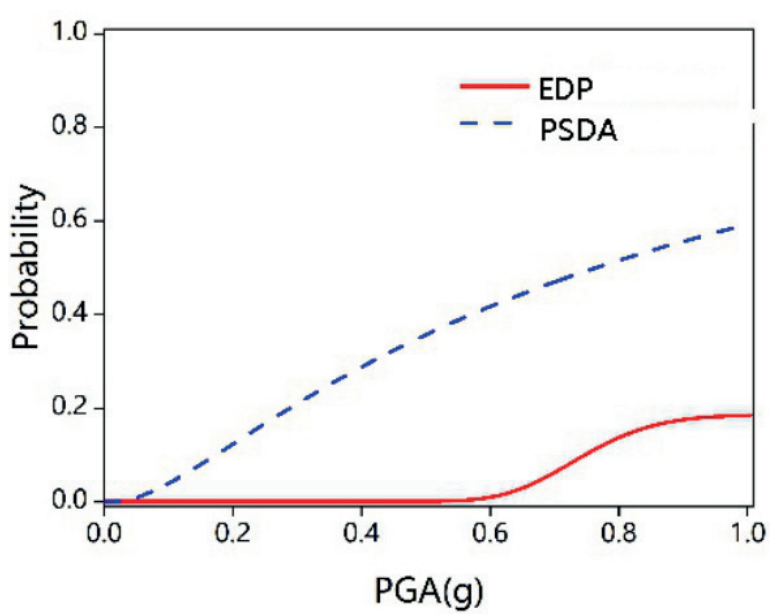

(a)

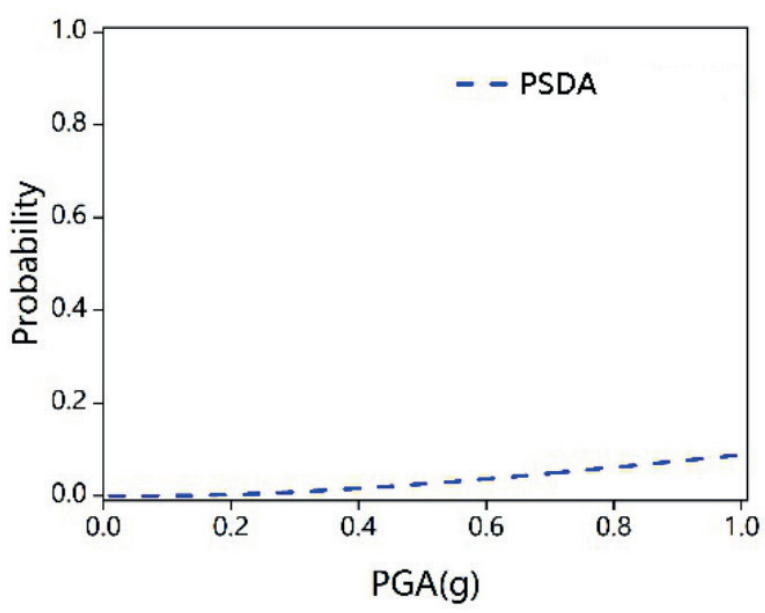

(b)

Fig. 11 Fragility curve of superstructure (inter-story drift as index), (a) LS1, (b) LS2

Although the deformation factor of the isolation bearing can be considered in the limit value of the story drift index, due to the lack of clear theory to establish the relationship between the story drift of the lower story and the deformation of the isolation bearing under the earthquake action, at present, the recommended limit value is often given by experience and calculation examples, which has certain limitations. In addition, as an important part of the isolation structure, the performance of the isolation bearing under the earthquake should be discussed in more detail. Therefore, this paper also takes the shear deformation of bearing ground as an index to establish the fragility curve.

Fig. 12(a)-(d) respectively show the fragility curves of the base isolated structure under the four defined limit states (DS1, DS2, DS3 and DS4) with the shear deformation of the isolation bearing as the index, which are based on the Probabilistic Seismic Demand Analysis (PSDA) and the Engineering Demand Parameter (EDP) criterion. 


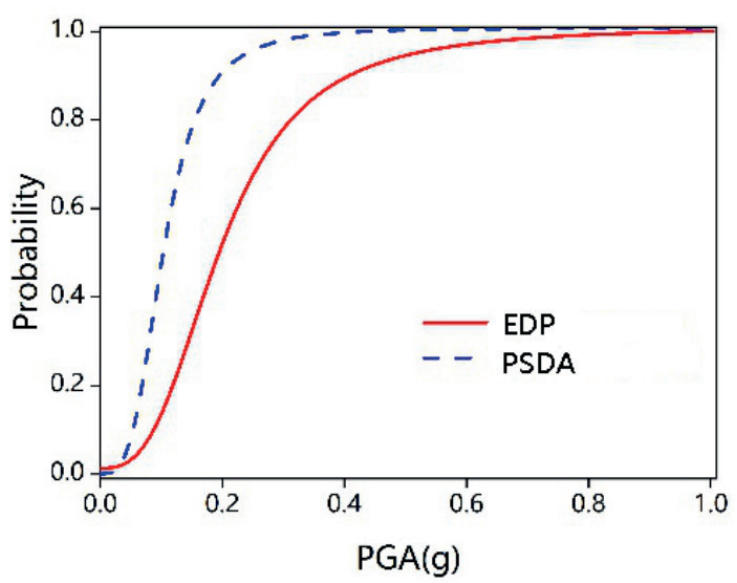

(a)

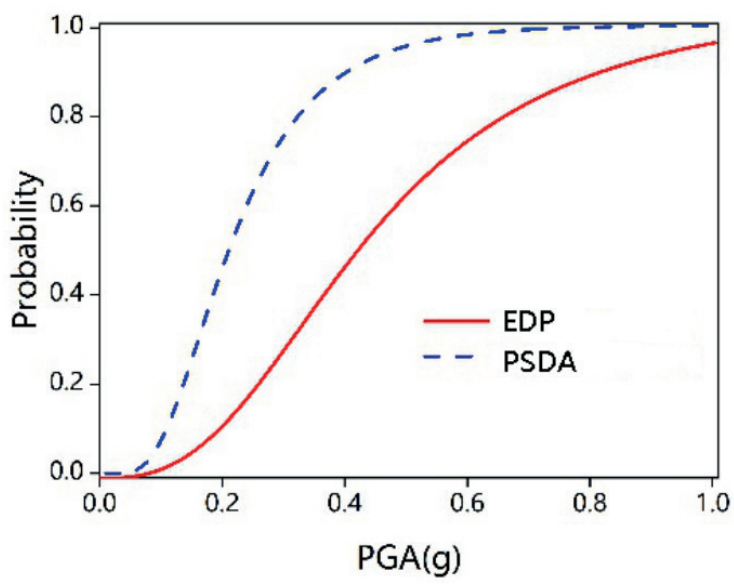

(c)

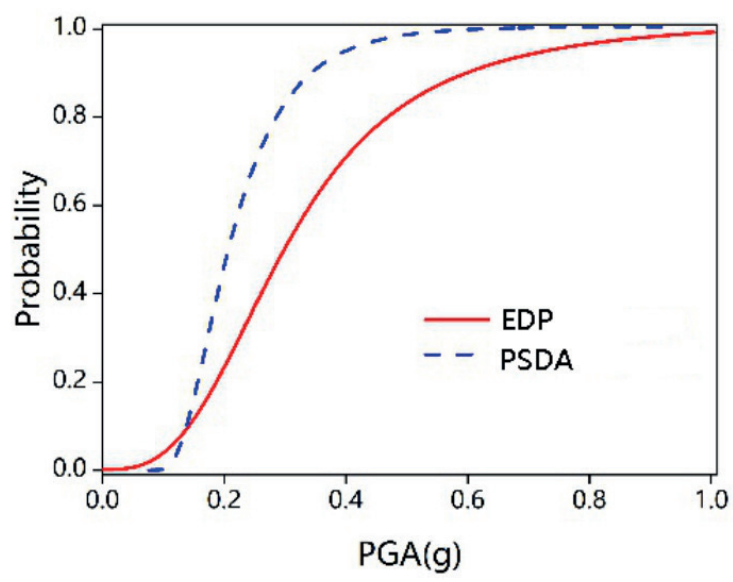

(b)

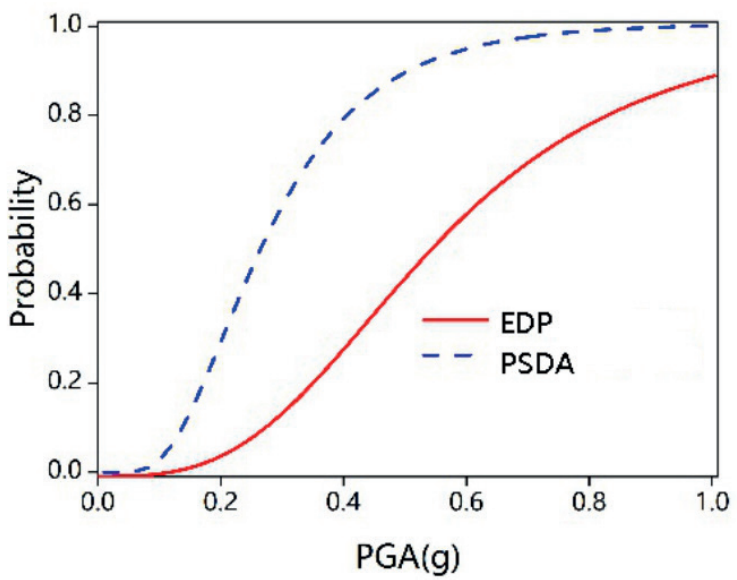

(d)

Fig. 12 Fragility curve of base isolation structure (bearing deformation as index), (a)DS1, (b) DS2, (c)DS3, (d) DS4

It can be found that the shear deformation of the bearing may even exceed the DS4 state under the near-fault earthquake action of $0.1 \mathrm{~g}-1.0 \mathrm{~g}$ variation of PGA. When the PGA is $1.0 \mathrm{~g}$, the probability of exceedance of the fragility curve established by EDP criterion reaches an amazing $90 \%$, and the probability of exceedance of the fragility curve proposed by PSDA is close to $100 \%$. Therefore, the damage of bearing cannot be ignored. When the PGA is $0.1 \mathrm{~g}-1.0 \mathrm{~g}$, the probability of shear deformation exceeding the corresponding state limit increases significantly with the increase of seismic intensity. According to the fragility curve established by EDP criterion, when PGA increases from $0.1 \mathrm{~g}$ to $0.4 \mathrm{~g}$, the probability of bearing shear deformation exceeding DS1 increases rapidly from $16 \%$ to $90 \%$. With the increase of limit value in state limit, the growth trend is relatively slow. Until PGA reaches $0.9 \mathrm{~g}$, the probability of bearing shear deformation exceeding DS2 increases to $90 \%$, and the growth trend of fragility curve corresponding to DS3 and DS4 is more gentle. For the limit state with smaller limit value, it may be necessary to pay special attention to a specific seismic intensity section in engineering practice, because the exceedance probability in this specific section may change significantly compared with other seismic intensity sections. This change in sensitivity can also be seen in the fragility curve established based on PSDA. Compared with the fragility curve established by EDP criterion, the curve based on PSDA has a greater probability of exceeding each limit state under the same PGA.

It can be seen from Fig. 11 and Fig. 12 that even though the same original sample points are used, there are some differences in the fragility curve established by EDP criteria and PSDA. The establishment of fragility curve based on PSDA is to assume that the ground motion intensity (IM) and damage index $(D M)$ are lognormal distribution, and the linear regression results of sample points obtained by nonlinear time history analysis in logspace directly establish a continuous fragility function. The establishment of fragility curve based on EDP criterion is to directly calculate the ratio of the samples whose structural response 
exceeds the limit value to the total number of samples under the same ground motion intensity, as the exceeding probability point under the current ground motion intensity, and then develop the discrete points into fragility curve through interpolation or regression. The fragility curve established by PSDA largely depends on the distribution assumption between seismic strength $(I M)$ and damage index $(D M)$, which is one of the reasons for the difference between the two methods in this paper. In the example of this manuscript the exceeding probability of fragility curve based on PSDA is larger than that based on EDP criterion to some extent. When the sample points of the two methods are the same, the exceeding probability points calculated based on PSDA can be regarded as accurate values. The fragility curve based on PSDA may overestimate the exceeding probability to some extent, and the overestimation may be enlarged with the increase of failure stage. It is safe to evaluate the performance of the base isolation under the earthquake action.

\section{Conclusions}

Under the earthquake action, the base isolated structure can effectively reduce the seismic energy input of the superstructure. However, under the action of near-fault earthquake, the base isolated structure may be damaged due to large displacement. Therefore, in order to evaluate the performance of the base isolated structure under the nearfault earthquake, this paper establishes a nonlinear finite element model of the base isolated structure, and discusses the dynamic characteristics and structural response of the base isolated structure. The incremental dynamic method is used to calculate the damage probability of the base isolated structure in different seismic capacity stages. The fragility curve is drawn and the fragility equation is obtained by nonlinear regression. The conclusion is as follows:

(1) Under the action of near-fault earthquake, the hysteretic behavior of rubber bearing is closely related to the characteristics of ground motion, and its displacement is not positively related to the peak ground acceleration (PGA). With the increase of ground motion intensity, the

\section{References}

[1] Hwang, J. S., Chiou, J. M. "An equivalent linear model of lead-rubber seismic isolation bearings", Engineering Structures, 18(7), pp. 528536, 1996.

https://doi.org/10.1016/0141-0296(95)00132-8

[2] Lu, Z., Chen, X., Zhou, Y. "An equivalent method for optimization of particle tuned mass damper based on experimental parametric study", Journal of Sound and Vibration, 419, pp. 571-584, 2018. https://doi.org/10.1016/j.jsv.2017.05.048 damage probability of base isolated structure increases correspondingly, but not linearly. The growth rate of damage probability with the earthquake intensity is closely related to the seismic capacity of the structure. The sensitivity of the growth rate of damage probability is different in various damage stages.

(2) When the PGA is less than $0.2 \mathrm{~g}$, the dispersion of the maximum response value of the lateral displacement and the story drift of the rubber isolation bearing under different ground motion records is small, and the dynamic response of the system at this stage is relatively insensitive to the variation of the spectrum characteristics of the ground motion records. With the increase of ground motion intensity, the discreteness of the maximum response of lateral displacement and story drift of the support increases, and the sensitivity of the dynamic response of the system to the spectrum characteristics of ground motion records increases.

(3) Compared with the fragility curve established by EDP criterion, the curve based on PSDA has a greater probability of exceeding in each limit state under the same PGA. The exceeding probability of fragility curve based on PSDA is larger than that based on EDP criterion to some extent. When the sample points of the two methods are the same, the exceeding probability points calculated based on PSDA can be regarded as accurate values. Therefore, the fragility curve based on PSDA may overestimate the exceeding probability to a certain extent, which may be enlarged with the increase of failure stage. This is the performance of the base isolation under the earthquake. It is safe to evaluate the performance of the base isolation under the earthquake action.

\section{Acknowledgment}

The financial support from the National Natural Science Foundation of China (No.51778538), the China Scholarship Council (No.201707005100), and the China-Indonesia Joint Research Center for High-speed Railway Technology (No. KY201801005) are acknowledged and sincerely appreciated by the authors.

[3] Malhotra, P. K. "Dynamics of seismic impacts in base-isolated buildings", Earthquake Engineering and Structural Dynamics, 26, pp. 797813, 1997.

https://doi.org/10.1002/(sici)1096-9845(199708)26:8<797::aid-eqe $677>3.0 . \operatorname{co} ; 2-6$

[4] Liu, C., Luo, X., Fang, D., Shi, C., Sarvar, S., Zhao, B. "Study on flexural stiffness of diagrid non-stiffened node based on four-spring assemblage model", Engineering Structures, 198, Article No. 109500, 2019. https://doi.org/10.1016/j.engstruct.2019.109500 
[5] Park, S. W., Ghasemi, H., Shen, J., Somerville, P. G., Yen, W. P., Yashinsky, M. "Simulation of the seismic performance of the Bolu Viaduct subjected to near-fault ground motions", Earthquake Engineering and Structural Dynamics, 33, pp. 1249-1270, 2004. https://doi.org/10.1002/eqe.395

[6] Komodromos, P., Polycarpou, P. C., Papaloizou, L., Phocas, M. C. "Response of seismically isolated buildings considering poundings", Earthquake Engineering and Structural Dynamics, 36, pp. 1605-1622, 2010. https://doi.org/10.1002/eqe.692

[7] Liu, C., Fang, D. "Robustness analysis of vertical resistance to progressive collapse of diagrid structures in tall buildings", Structure Design Tall Special Building, 29, Article ID e1775, 2020. https://doi.org/10.1002/tal.1775

[8] Polycarpou, P. C., Komodromos, P. "On poundings of a seismically isolated building with adjacent structures during strong earthquakes", Earthquake Engineering and Structural Dynamics, 39, pp. 933-940, 2010.

https://doi.org/10.1002/eqe.975

[9] Liu, C., Yang, W., Yan, Z., Lu, Z., Luo, N. "Base Pounding Model and Response Analysis of Base-Isolated Structures under Earthquake Excitation", Applied Sciences, 7(12), Article No. 1238, 2017. https://doi.org/10.3390/app7121238

[10] Ahmadipour, M., Alam, M. S. "Sensitivity analysis on mechanical characteristics of lead-core steel-reinforced elastomeric bearings under cyclic loading", Engineering Structures, 140, pp. 39-50, 2017. https://doi.org/10.1016/j.engstruct.2017.02.014

[11] Fujita, T., Fujita, S., Tazaki, S., Yoshizawa, T., Suzuki, S. "Research, Development and Implementation of Rubber Bearings for Seismic Isolation", JSME International Journal, 33(3), pp. 394-403, 1989. https://doi.org/10.1299/jsmec1988.33.394

[12] Abe, M., Yoshida, J., Fujino, Y. "Multiaxial Behaviors of Laminated Rubber Bearings and Their Modeling. I: Experimental Study", Journal of Structural Engineering, 130(8), pp. 1119-1132, 2004. https://doi.org/10.1061/(ASCE)0733-9445(2004)130:8(1119)

[13] Jiang, Y. C., Nie, S. F., Ye, Z. X., Li, L. "Experimental study on mechanical properties of multi-lead rubber bearing and its explicit finite element analysis", Engineering Mechanics, 25(7), pp. 11-17, 2008. (in Chinese)

[14] Cardone, D., Gesualdi, G. "Experimental evaluation of the mechanical behavior of elastomeric materials for seismic applications at different air temperatures", International Journal of Mechanical Sciences, 64(1), pp. 127-143, 2012. https://doi.org/10.1016/j.ijmecsci.2012.07.008

[15] Dezfuli, F. H., Alam, M. S. "Multi-criteria optimization and seismic performance assessment of carbon FRP-based elastomeric isolator", Engineering Structures, 49, pp. 525-540, 2013. https://doi.org/10.1016/j.engstruct.2012.10.028

[16] Ohsaki, M., Miyamura, T., Kohiyama, M., Yamashita, T., Yamamoto, M., Nakamura, N. "Finite-element analysis of laminated rubber bearing of building frame under seismic excitation", Earthquake Engineering and Structural Dynamics, 44, pp. 1881-1898, 2015. https://doi.org/10.1002/eqe. 2570
[17] Jangid, R. S., Kelly, J. M. "Base isolation for near-fault motions", Earthquake Engineering and Structural Dynamics, 30, pp. 691-707, 2001.

https://doi.org/10.1002/eqe.31

[18] Liu, C., Zhao, B., Yang, J., Yi, Q., Yao, Z., Wu, J. "Effects of braceto-chord angle on capacity of multi-planar CHS X-joints under outof-plane bending moments", Engineering Structures, 211, Article No. 110434, 2020. https://doi.org/10.1016/j.engstruct.2020.110434

[19] Diaferio, M., Foti, D. "Mechanical behavior of buildings subjected to impulsive motions", Bulletin of Earthquake Engineering, 14, pp. 849-862, 2016. https://doi.org/10.1007/s10518-015-9848-5

[20] Mazza, F., Vulcano, A. "Effects of near-fault ground motions on the nonlinear dynamic response of base-isolated r.c. framed buildings", Earthquake Engineering and Structural Dynamics, 41, pp. 211-232, 2012. https://doi.org/10.1002/eqe.1126

[21] Fang, D. J., Du, Y. F., Liu, C. Q., Deng, Y. Y. "Analysis for displacement response characteristics of complex multi-layer base-isolated structure under near-field ground motion", Journal of Southwest Jiaotong University, 55(1), pp. 158-166, 2019. (in Chinese) https://doi.org/10.3969/j.issn.0258-2724. 20181038

[22] Nagarajaiah, S., Xiaohong, S. "Response of Base-Isolated USC Hospital Building in Northridge Earthquake", Journal of Structural Engineering, 126(10), pp. 1177-1186, 2000. https://doi.org/10.1061/(ASCE)0733-9445(2000)126:10(1177)

[23] Yang, J. N., Agrawal, A. K. "Semi-active hybrid control systems for nonlinear buildings against near-field earthquakes", Engineering Structures, 24(3), pp. 271-280, 2002. https://doi.org/10.1016/S0141-0296(01)00094-3

[24] Jangid, R. S. "Optimum friction pendulum system for near-fault motions", Engineering Structures, 27(3), pp. 349-359, 2005. https://doi.org/10.1016/j.engstruct.2004.09.013

[25] Jangid, R. S. "Optimum lead-rubber isolation bearings for near-fault motions", Engineering Structures, 29(10), pp. 2503-2513, 2007. https://doi.org/10.1016/j.engstruct.2006.12.010

[26] Providakis, C. P. "Effect of supplemental damping on LRB and FPS seismic isolators under near-fault ground motions", Soil Dynamics and Earthquake Engineering, 29(1), pp. 80-90, 2009. https://doi.org/10.1016/j.soildyn.2008.01.012

[27] Tajammolian, H., Khoshnoudian, F., Rad, A. R., Loghman, V. "Seismic Fragility Assessment of Asymmetric Structures Supported on TCFPBearings Subjected to Near-field Earthquakes", Structures, 13, pp. 66-78, 2018. https://doi.org/10.1016/j.istruc.2017.11.004

[28] Mazza, F. "Seismic demand of base-isolated irregular structures subjected to pulse-type earthquake", Soil Dynamics and Earthquake Engineering, 108, pp. 111-129, 2018. https://doi.org/10.1016/j.soildyn.2017.11.030

[29] Mazza, F., Mazza, M., Vulcano, A. "Base-isolation systems for the seismic retrofitting of R.C. framed buildings with soft-storey subjected to near-fault earthquakes", Soil Dynamics and Earthquake Engineering, 109, pp. 209-221, 2018. https://doi.org/10.1016/j.soildyn.2018.02.025 
[30] Ellingwood, B. R. "Earthquake risk assessment of building structures", Reliability Engineering and System Safety, 74, pp. 251-262, 2001.

https://doi.org/10.1016/S0951-8320(01)00105-3

[31] Shinozuka, M., Feng, M. Q., Lee, J., Naganuma, T. "Statistical Analysis of Fragility Curves", Journal of Engineering Mechanics, 126(12), pp. 1224-1231, 2000. https://doi.org/10.1061/(ASCE)0733-9399(2000)126:12(1224)

[32] Liu, C., Fang, D., Zhao L. "Reflection on earthquake damage of buildings in 2015 Nepal earthquake and seismic measures for post-earthquake reconstruction", Structures, 30, pp. 647-658, 2021. https://doi.org/10.1016/j.istruc.2020.12.089

[33] Chopra, A. K. "Dynamics of Structures: Theory and Applications to Earthquake Engineering", Pearson Education, London, UK, 2014.

[34] Mander, J. B., Priestley, M. J. N., Park, R. "Theoretical Stress $\square$ Strain Model for Confined Concrete", Journal of Structural Engineering, 114(8), pp. 1804-1826, 1988.

https://doi.org/10.1061/(ASCE)0733-9445(1988)114:8(1804)
[35] Menegotto, M., Pinto, P. E. "Method of analysis for cyclically loaded R.C. plane frames including changes in geometry and non-elastic behavior of elements under combined normal force and bending", International Association for Bridge and Structural Engineering, Zurich, Switzerland, IABSE Report ,1973.

http://doi.org/10.5169/seals-13741

[36] Stewart, J. P., Chious, S.-J., Bray, J. D., Graves, R. W., Somerville, P. G., Abrahamson, N. A. "Ground motion evaluation procedures for performance-based design", Soil Dynamics and Earthquake Engineering, 22, pp. 765-772, 2002.

https://doi.org/10.1016/S0267-7261(02)00097-0

[37] Du, Y. F., Wang, G. H. "Performance levels classification and performance index quantitative analysis of base-isolated RC frame", Earthquake Resistant Engineering and Retrofitting, 30(6), pp. 87-97, 2013. (in Chinese)

https://doi.org/10.3969/j/issn.1002-8412. 2013.06.016 